\title{
Generational Change: Implications for the Development of Future Military Leaders
}

\section{Paul Whelan*}

In the last decade, the raison d'être of the international military environment has experienced a transition in scope and perspective. These changes in military perspective have an impact on the way the military interacts with both the professional and nonprofessional world within which it operates. Employee aspirations and attributes are evolving too. Today's employees exhibit values and aspirations different from their older generational counterparts. Both of these factors conspire to paint an altered and challenging landscape for the practice of leadership and management in the military in future years.

This paper will address the future of military leadership and management within the context of generational change among its management employees. It will outline this future in the context of the new and wider purpose of the Irish Defense Force. It will present current evidence gathered from the science of organizational behavior and management, and contrast this evidence with the model of training and socialization processes that the Irish military currently applies to cadets and newly commissioned officers, or more appropriately, the military managers of the future.

\section{The Corporate Military}

S.C. Sarkesian, a scholar of organization and management, has written that "all professions are corporate in nature." Sarkesian, a former U.S. Army officer, argues that all corporations employ a system of bureaucracy and adhere to specific rules and regulations. He suggests that all professions embrace certain values, ethics, and ideals in the conduct of their business that are unique to each profession. They maintain standards of performance by which they gauge progress. Professions employ and mold their members to share in the common corporate goal of achieving legitimacy of purpose. Sarkesian posits that the modern military, as a profession, is substantially similar in concept to a corporation. ${ }^{2}$ The models of practice outlined above could equally apply to the military as they do to a profession such as law or business. However, the understood role of the international military has changed dramatically from the roles that had been defined for it in previous decades. These changes are currently reflected in the

* Commandant Paul Whelan is a serving officer in the Irish Defense Forces, having just completed his country's Staff Course at the Command and Staff School, The Curragh, County Kildare, Ireland, and the Masters Degree in Leadership, Management and Defense Studies through the National University of Ireland. This is an edited version of his Masters' Thesis.

1 S.C. Sarkesian, The Professional Army Officer in a Changing Society (Chicago: Nelson Hall Publishers, 1975), 9.

2 Ibid., 10. 
international security strategies of both the United States and Europe. ${ }^{3}$ These changes have also been acknowledged in the Irish Defense Forces: "One thing that comes up in every discussion is the transformation process that seems to be ongoing in all forces today, and the fact that as transformation is ongoing, the operational demands are increasing and becoming more diverse and complex in nature." 4

Essentially, the modifications of military purpose have had the effect of moving the military model even closer to that of a professional corporation. ${ }^{5}$ For military formations internationally, the possibility and probability of participation in total war has declined. Instead, the prospect of involvement in total war has been replaced by a higher likelihood of joint participation in counter-terrorism efforts, low-intensity conflicts, limited wars, high technology information warfare, and a diverse array of peace operations. This new range of missions has brought about a necessary shift in focus for today's military organization. "The emphasis on technology and scientific knowledge has transformed the military from a parochial, inbred instrument of land battle to a highly sophisticated, multi functional organization closely linked to society." ${ }^{6}$ Aligned with these changes of purpose, the military today are working in increasingly active cooperation with an ever-widening range of other military, non-military, and professional organizations. These circles may be political, civil, corporate, or non-governmental.

\section{The Military's New Professional}

A corollary of the organizational changes that are sweeping the cultures of both the corporation and the military is the idea that "employees are changing too."7 Today's professionals embrace different values, attributes, and aspirations for their working lives when compared to their counterparts in earlier generations. They view the world differently from the way their parents might have viewed it. From an early age, today's generation of young and aspiring employees has recognized and mentally registered the trials and traumas confronted by their parents in an era when economies, politics, employment values, and employment rules were vastly different from today's. ${ }^{8}$ They have grown up alongside technology and innovation and, having been exposed to computer technology from a young age, they are comfortable with change and motivated by technological advancement. They are inquisitive. They are generally well-traveled. Through modern approaches to parenting, and through more open and conscientious schooling, today's generation possess a better understanding and a better acceptance of

3 See George W. Bush, The National Security Strategy of the United States of America (Washington, D.C.: The White House, 2002),13; and European Security Strategy (2002), 3.

4 Lt. Gen. J. Sreenan, transcript of speech presented to the $62^{\text {nd }}$ Command and Staff Course, The Curragh, County Kildare, Ireland (24 February 2006), 1.

5 Walter F. Ulmer, Jr., “Military Leadership into the $21^{\text {st }}$ Century: 'Another Bridge Too Far?’” Parameters (Spring 1998): 6.

6 Sarkesian, Professional Army Officer, 8.

7 A. Kakabadse, J. Bank, and S. Vinnicombe, Working in Organisations, The Essential Guide for Managers in Today's Workplace, $2^{\text {nd }}$ ed. (London: Penguin, 2005$), 47$.

8 Catherine Loughlin and Julian Barling, "Young Workers' Work Values, Attitudes, and Behaviors,” Journal of Occupational and Organizational Psychology 74:4 (2001): 545. 
different cultures, nations, and societies. ${ }^{9}$ They therefore possess attributes and values that distinguish them from previous generations. This generation represents the newest entrants to the workplace, and is popularly referred to as "Generation Y."10

\section{Personal Perspective}

Since my commissioning in early 1991, I have held varied levels of responsibility for the selection, employment, and training of military cadets. I have spent the vast majority of my career training cadets and young officers in both the academic study of flight and in the skilled discipline of military flying itself. In that time I have witnessed a tangible transition in the type of person I am educating. During my early days of instructorship, when training someone to fly, I would always imagine myself in the student's place. By doing so, and by taking due cognizance of his or her capability, personality, and attitude, I felt able to deliver more considered, relevant, and effective instruction. I became more aware of the student's possible reactions, and the fact that these reactions would probably and usually coincide with my adopted position. I therefore became more capable of providing an appropriate response or reaction to situations or problems presented by the student.

As my experience as an instructor progressed, however, I found this process increasingly difficult to apply. I felt that a disconnection was taking place between my students and myself, and that this disparity, at least to me, was based on personality.

On mature reflection, the student and I were on diverging paths. I, fixed in my methods and responses, was moving further away from the student as the years passed and the faces changed. The student's attributes, attitudes, aspirations, and outlooks were becoming increasingly different from mine. The younger students were changing, and I remained firmly fixed in my generation, and therefore wedded to my methods of instruction.

The members of this younger generation are different people. They question and challenge professional direction more frequently. They actively seek considered and honest guidance, and despair when none is forthcoming. I learned that newer employees' initial career expectations could be thwarted by meaningless direction from their superiors. I also learned that the psychological contract that exists between employer and employee requires constant and considered attention at the employment entry phase and thereafter. Active and considered employee socialization processes, or "onboarding" efforts, on behalf of the new employer can serve to successfully guide the new employee toward a clearer and more considered approach to their new career.

\section{What Is “Generational Change”?}

Generations are defined not by a formal process, but rather by demographers, popular culture, the press and media, and even by the generations themselves. The differences

9 R. Zemke, C. Raines, and B. Filipczak, Generations at Work (New York: AMACOM, 2000), 137.

10 Bruce Tulgan and Carolyn Martin, Managing Generation Y: Global Citizens Born in the Late Seventies and Early Eighties (Boston: HRD Press, Inc., 2001), xi. 
in personality experienced and recognized by organizations in their managers, both young and old, are categorized as "generational." The majority of literature emanating from the discipline of organizational behavior dealing with this topic of generational change is American in origin, and thus applies its focus to a Western style of organizational behavior. While slight discrepancies exist in the identification and categorization of the various generations, delineations have nevertheless been made in the literature that delineate the various generational cohort groups for the purposes of study.

In order to enable clarity of definition, I will begin with the "Silent Generation," as the portrayal of this generation allows more clearly definitive comparisons to be drawn when examining today's generation, Generation Y. Examining the two generations that reside between these extremities allows an appreciation of the evolution of the values attributed to Generation Y.

\section{The Silent Generation}

Most analysts date the birth of members of the Silent Generation between 1925 and 1942. Despite some debate about the exact dates, virtually all authors broadly agree on the attributes and values of this cohort group, as its members were influenced by the historical and social conditions of their time. Essentially, this generation is approaching or has already concluded its working life in the professional world. Some scholars have posited that the Silent Generation was the product of families that lived through the Great Depression, and that they were influenced by the difficulties that their parents faced to treasure employment and to be loyal employees, and by their parents' generation's service in the military during the Second World War to be command-oriented in the way that they managed their employees. The Silent Generation spent their early management careers in a post-war world that rarely, if ever, questioned authority, adhered to rather rigid chains of command, and observed a system of honor, subservience, and reverence for seniority. They are disciplined in that they are willing to accept poor direction, even when they know it to be flawed, and tend to tolerate it silently. They believe resolutely in law and order and are conservative by their nature.

\section{The Baby Boomers}

The birth years of the next generational cohort, known as the Baby Boomers, are usually held to be between 1943 and 1964. Particularly in the case of the United States, this generation was born into an era of rebellion and post-war national wealth, and their views were shaped by the emergence of the counterculture in the 1960s, the Vietnam War, and the Watergate scandal, all of which served to call into question established forms of authority. These trends would be mirrored in much of Europe, as in the 1968 student uprising in Paris. For this generation, authority appeared increasingly unreliable, an object of suspicion. They were further influenced by the styles of idealism proffered by emerging leaders such as Martin Luther King, Jr. and John F. Kennedy. According to one group of scholars, this cohort group believe in growth and expansion, take great pride in themselves as professionals, are optimists, are oriented towards 
teamwork, and have "pursued their own personal gratification uncompromisingly, and often at a high price to themselves and others."11

\section{Generation X}

The next generational cohort, which has been dubbed Generation X, was born between 1960 and 1980. This generation lacked the experience of growing up through "real" wars that the two generations discussed above experienced. Members of Generation X are described by Zemke as being self-reliant, seeking a work-life balance and placing greater importance on family. Their approach to authority is casual and sometimes skeptical. They also possess a greater level of comfort with technology, having grown up in the computer age. Personal sacrifice for professional work advancement, which was so well practiced by older generations, has relatively little appeal for members of Generation X. "In a nutshell, they distrust hierarchy. They prefer more informal arrangements. They prefer to judge on merit rather than on status. They are far less loyal to their companies."12

\section{Generation $Y$}

A fourth group is now in evidence-Generation Y, or the "Millenials," a cohort made up of those born after 1980. This group is now making its presence felt within the professional world. Members of Generation Y are relative newcomers to the workforce, but early indications are that they are highly motivated and actively seek to improve their skills and abilities. They are not averse to questioning authority and, like the members of Generation X, lack permanent affiliation or commitment to their job. Martin, et al. describe this generation as one possessed with much aplomb. They are a "generation of new confidence, upbeat and full of self-esteem," perhaps not surprising as they "grew up basking in the 'decade of the child', a time when humanistic theories of childhood psychology permeated counseling, education and parenting." ${ }^{3}$ They state that this period of psychological parenting has taken place under the cloud of isolation brought about by absentee double-income parents, often being raised by nannies or other non-parental caregivers. Generation Y has been brought up in environments that advocate that career-minded parents pursue their professional ambitions, while their children reside within a care environment or fend for themselves, independent of sustained parental presence and interest. By way of replacement, through access to vastly more information than was available to previous cohorts, this generation learns of the world's ills through the proliferation of electronic media.

These four generational dimensions, distinct and complete, are each products of the eras in which they grew up. Their values have been shaped and oriented according to the various political, environmental, and social backdrops to which they were exposed

11 Ron Zemke, Claire Raines, and Bob Filipczak, Generations at Work: Managing the Clash of Veterans, Boomers, Xers, and Nexters in Your Workplace (New York: American Management Association, 1999), 67.

12 Jay A. Conger, Winning 'Em Over: A New Model for Management in the Age of Persuasion (New York: Simon \& Schuster, 2001), 9.

13 Tulgan and Martin, Managing Generation Y, 4. 
and against which they were raised; in turn, they defend and promote these virtues throughout their working lives. Generations are delineated by major world-historical events, such as the period of the Great Depression, the World Wars, Vietnam, cultural rebellion in the 1960s, the attacks of 9/11, etc. These events redefine ideology and social behavior; they are true "paradigm shifts," in that they reshape and alter people's intellectual approaches to the world.

\section{Questioning Authority}

The subject of generational value differences is important in the context of organizational behavior, in that it raises questions about generational conflict in management, management employee permanence, socialization processes, and a host of other issues. Sarkesian, writing of the civilianization of the military profession, remarks that it has "taken on the characteristics of a civilian profession, and in doing so has opened itself not only to reassessment and criticism by its own members but also by outsiders." ${ }^{14} \mathrm{He}$ refers to the organizational conflict that can arise between the older, more traditionalist officer and his younger subordinate. He states: “Traditionalists have a tendency to perpetuate the heroic role of the military, while the more modern and liberal professionals feel that the military must do more than manage violence."15 Sarkesian highlighted this internal conflict in 1975, at a time when U.S. military focus was still centered on the Cold War.

More recently, an article written by Walter F. Ulmer, Jr. for the journal Parameters in the United States highlighted the issue again: "A survey sponsored by the Army Command and General Staff College in 1995 found some concerns about leadership and the command climate strikingly similar to those reported in the 1970 Army War College Study on Military Professionalism."16 Ulmer continues, "Many senior service college students in recent classes seem to display more than typical student skepticism about the quality of senior leaders they have observed. Anecdotes about poor leadership, particularly at the field grade and general officer levels, are too persistent to ignore." 17

In addition to highlighting various levels of dissent regarding elements of seniority, Ulmer in his article suggests that the increase in questioning of authority is linked to organizational changes associated with the modern military. He highlights the organizational qualities required in the officer ranks of today, in addition to the traditional traits and characteristics of leadership. He also notes the civilianization of the military, and calls for more effective work in the management of organizational change.

What both Sarkesian and Ulmer present, albeit only as part of their overall work, is evidence of the increasing tendency to question the viability of leadership and authority by military juniors or subordinates in the modern era. The time of unquestionable honor and reverence for leadership, as described by Conger in his appraisal of the Si-

14 Sarkesian, Professional Army Officer, 14.

15 Ibid.

16 Ulmer, "Military Leadership into the $21^{\text {st }}$ Century," 2.

17 Ibid. 
lent Generation, has passed. The new generations (both X and $\mathrm{Y}$ ) do not simply accept direction out of obligation, and feel justified in seeking qualification, clarification, and justification for the orders they are given.

This questioning tendency is further developed in an article by Catherine Loughlin and Julian Barling. They suggest that, "Many young workers do not attach the same status to authority as previous generations, and there is now a pervasive cynicism about leadership and leaders." ${ }^{\text {"18 }}$ It could be contended that "cynicism" in this context is a little harsh. It is possible that, through questioning, conflict and contradiction may emerge in the authority figure's qualifications, which in turn may disappoint the expectations of the questioner.

\section{Practical Implications for Organizations}

Kakabadse, et al. state: "The idea of a lifelong career in one company, quite common in the past, seems increasingly remote today." Today's new employees "develop new competencies and stay with an organization only as long as they find it challenging."19 So what acknowledgement should organizations today make in recognition of the newer generational employee?

In his research paper and case study written on the generational implications of organizational behavior for the Australian Defense Forces (ADF), Bradley Jorgensen takes a critical look at the aspects of generational change. He tests the applicability of the hypothesis that generational issues should be accounted for in the design of workplace policy for the ADF. He acknowledges the differing approach to careers taken by Generations $\mathrm{X}$ and $\mathrm{Y}$, paying particular attention to their inquisitive nature, their independence, their loyalty, and their skills and expertise in technology. He notes "that intention to leave increases markedly in line with educational attainment." ${ }^{, 20}$ He notes in particular an attribute of the newest generation, in that the Generation Y cohort "values skill development and thrives on [the socialization aspect of] mentoring/coaching" and that, "like the Generation X cohort, they are motivated to do work but seek more direction and meaning in their work. They are not afraid to question authority, and will challenge management decisions that they deem unreasonable."21

This particular study by Jorgenson concludes: "The claims put forward by generational writers regarding the need to manage workforce through generationally-targeted mechanisms lack the necessary rigor on which to base workforce policy decisions. Rather, academic literature appears to support the notion of individualization and tailored measures rather than bulk or generic workforce policy approaches." ${ }^{22}$ The recommendations proffered by Jorgenson, in my opinion, offer sound and qualified judgment. However, the recommendations may have been made in the knowledge that ex-

18 Loughlin and Barling, “Young Workers’ Work Values, Attitudes, and Behaviors,” 551-52.

20 Bradley Jorgensen, "Baby Boomers, Generation X, and Generation Y: Policy Implications for Defence Forces in the Modern Era,” Foresight 5:4 (2003).

21

22 Ibid., 4; Tulgan and Martin, cited in Jorgenson.

Jorgenson, "Baby Boomers." 
isting training, management, and socialization techniques in the ADF already calculate to a large extent for generational difference. The reference to "individualization" is important, as it raises the issue of the socialization and mentoring of employees both on and after initial employment. This is the period during which notional expectations of employment on the part of both the employer and the employee are either confirmed or undermined, and may present a valuable tool toward determining employee career dedication and career permanence.

Ulmer states that, in relation to the U.S. military, there presently are "no highly visible, heavily resourced efforts to define, inculcate and monitor the creation and sustainment of organizational climates that challenge, inspire, and motivate all ranks."23 According to Ulmer, the practice of mentoring in the military is restricted to the annual “Officer Efficiency Report," which he finds to be insufficient. Organizational best practices in the area of "developmental feedback and monitoring," he concludes, have left the military behind. ${ }^{24}$

\section{The Socialization Process}

In essence, the aforementioned body of literature provides an overview of the change in the military's approach to the newer generations ( $\mathrm{X}$ and $\mathrm{Y}$ ) and their employment. These generational cohorts utilize a different approach to authority than their predecessors, the Silent Generation and, to a lesser extent, the Baby Boomers. Issues of generational conflict are highlighted in the wish by newer generations to constantly seek direction, qualification, and purpose from their employers. This quest, from my own experience, is conducted unashamedly and with ample merit.

One method of guiding new employees through the mist of the first stages of a new position is through the utilization of considered socialization techniques. Socialization, whether consciously or not, is a method used by the Irish Defense Forces to extend the training acquired through the Cadet School and apply this training to employment practice. While socialization within the Irish military is not currently a discretely identified process after a cadet's commissioning - that is, it is not monitored or controlled by any training or management body - it can and does form a vital component of the individual's induction into the organization. It also makes a definite and lasting impression upon the employee.

As stated at the beginning of this paper, military employees are involved now more than ever with a widening circle of military, non-military, and civilian organizations. ${ }^{25}$ The emphasis of such contact has shifted away from one directed toward purely military objectives. This diversification of professional contact requires that military offi-

${ }^{23}$ Ulmer, "Military Leadership into the $21^{\text {st }}$ Century," 6.

24 Ibid.

25 See Sarkesian, Professional Army Officer; Ulmer, "Military Leadership into the $21^{\text {st }}$ Century"; and M. Vlachova and L. Halberstat, "A Casual View into the Future: Reform of Military Education in the Czech Republic," Geneva Centre for the Democratic Control of Armed Forces, Working Paper No. 105 (2003); at www.dcaf.ch/publications/Working_Papers/ 105.pdf (accessed on 2 December 2005). 
cers and personnel be equipped professionally with the wider relationship skills required for such associations. Effective socialization processes through peer or superior mentoring can serve to foster and develop appreciation of the skilled requirements of diplomacy.

Through socialization, the initial expectations of the employee are tested against the reality of the job, and a tentative adjustment in attitude and behavior can then take place. ${ }^{26}$ Initial military training falls under the category of "divestiture" in socialization terms. ${ }^{27}$ Through divestiture, one tries to deny and/or change the identity of the newcomer. There follow, then, two methods of socialization, as proposed by Ardts, et al.:

- Institutionalized socialization and personnel instruments

- Individualized socialization and personnel instruments.

Institutionalized methods of socialization are selected "when one wants conformist newcomers that have little intention to leave the company, that are loyal and emotionally committed to the organization." ${ }^{28}$ This is a method of formalized socialization. The method or program makes use of a mentor or role model, and aims toward the affirmation of the new employee's own identity and quality.

Individualized methods of socialization are selected "when one wants innovative newcomers, and does not want to offer them a job for life, and if one is less concerned about newcomers that are loyal and that feel emotionally attached to the organization." 29 This method does not employ a mentor to facilitate the process. It may be done on an ad hoc basis, without clearly defined steps and without a predetermined time frame.

Allowing that there is no clearly established method or framework of socialization recognized and undertaken by the Irish military after commissioning (with the exception of the AF451, the Officer's Annual Performance Appraisal), it follows that the IDF utilizes individualized socialization methods after the period of initial military training. In theory, then, the employee is allowed to construct their own understanding of the organization based on their own immediate experience, which in an organization as diverse as a nation's military can serve to undermine the previous beliefs and/or career expectations of the employee and thwart their potential for self-actualization.

\section{Indications}

The need for a high level of intellectual capability within the military will not diminish. In order to maintain and embellish both its self-image and its image with respect to society - especially while cooperation with society increases in response to a widening of the military's roles - education must be high on the military agenda. The forces of history and societal evolution have presented a new variant of generational cohort who

26 See Kakabadse, et al., Working in Organisations.

27 J. Ardts, P. Jansen, and M. van der Velde, “The Breaking in of New Employees,” Journal of Management Development 20:2 (2001): 159-67.

Ibid., 163.

Ibid. 
will fulfill the duties of management well into the future. However, Generations X and $\mathrm{Y}$ are somewhat fickle cohorts. The psychological requirement for self-improvement exhibited by these generations reflects the motivational theories of Maslow, but qualifies even further the "needs" theories of Alderfer, in that, "If a need is consistently frustrated, an individual 'regresses' to being motivated by lower-order needs that are already being fulfilled to a sufficient degree.”30

Studies in organizational psychology and behavior have identified the aspirations and values of the new employee/managers of the future, Generation Y. They are an impressive generation. They symbolize the progressive, inquisitive qualities that qualify general evolutionary thought. They require honest and meaningful direction, and they seek it voraciously.

Generation Y's inquisitive nature, however, is amplified by a marked reluctance to simply adhere to direction and authority without question. Direction and authority must be both qualified and justified. This questioning of leadership is readily identified in youth society today, and is equally apparent within the military environment. New generations of employees, while lacking the kind of career permanence that their Silent Generation predecessors possessed, will nevertheless relish organizational systems of training and socialization that serve to satisfy the intangibility of career expectation. Effective and meaningful socialization techniques can serve to assist development processes while diminishing career apathy and unmet expectations among newer employees.

Is it possible, however, that older generations will always view younger generations as being "difficult to deal with," "argumentative," and as "having no persistence," not just in relation to their careers but to all undertakings? The quality of an even, consistent pace has always been associated with older generations, who are thought to prefer to control, manage, and maintain their affairs carefully and deliberately. The converse has always been imputed to younger generations, with the assumption being that they prefer to take risks and seize opportunities as they arise. Criticisms relating to younger generations are not a new phenomenon, and can be traced back (at least) to ancient Egyptian manuscripts. Is it possible, though, that the theories that define generational change are simply an attempt to psychologically categorize what has been known throughout history? Jorgenson posits this possibility in his assessment of generational change effects and their implications for the ADF. In any assessment of generational change, however, credence must be given to the societal and historical background from which the different generations grew. Today's new employees are the products of a society that possesses values that are markedly different from those of their parents.

The previous focus within military organizations on roles that are purely focused on military tasks, narrowly defined, is being quickly replaced by new and widening liai-

${ }^{30}$ See A. H. Maslow, Motivation of Personality (New York: Harper and Row, 1954); and C. P. Alderfer, Existence, Relatedness and Growth: Human Needs in Organizational Settings (Boston: Free Press, 1972). Quote from Alderfer, cited in M. Morley, S. Moore, N. Heraty, M. Linehan, and S. MacCurtain, Principles of Organisational Behaviour, An Irish Text, $2^{\text {nd }}$ ed. (Dublin: Gill \& Macmillan, 2004). 
sons that require new levels of professionalism. The lines of demarcation are being rewritten, and as the military diversifies into its new roles, the training and socialization of new employees needs to reflect the levels of managerial professionalism required to meet the military's new missions. Examining the motivations and future expectations of these new employees may provide a valuable insight into the aspirations of the military manager of the future.

The theory of generational change holds that today's employee, a member of Generation Y, displays different aspirations and attitudes in his/her approach to work and life than did members of earlier generations. Do the Irish Defense Forces therefore need to alter their approach to accommodate this difference, in terms of its methods of training and its practices of socialization?

\section{Square Pegs and Round Holes}

When reflecting on the lives of past generations, one tends to reflect on the qualities, the characteristics, and the tempo of the era in question. Life almost always appears to have been simpler in the past compared to the present. This simple reflective practice applies to all generations. When I began this thesis, I did so in the assured knowledge that the cohort I had identified, Generation Y, was somehow removed from me psychologically, and that their lives certainly reflected complicated influences that were unknown to me in my own formative years. Would it be feasible or even possible, however, to use an American model of generational delineation as a framework within which to evaluate an Irish generational equivalent in terms of chronological placement, attitudes, and traits? In my journey through the construction of this thesis, I have learned that the practice of attaching concrete rules and codes of behavior to an identified group of people can quickly become problematic. In many ways, deeply demographic studies amplify modern values in teaching us that no single, definitive scientific truth may be applied in its totality to the study of a complete generation. As Ryder summarizes, "It is invalid to transform a proposition about populations into a proposition about individuals." 31 The application, however, of a "simplification of values" that encompasses the expected attributes of a given generation, a generality of traits that distinguish one generation from another, can be constructive in the evaluation of predicted impacts upon society and, through more focused application, upon organizations.

\section{Messages that Motivate}

The Irish Defense Forces today coexists with a highly competitive corporate environment in which the institution of human resource management has emerged as an element of critical organizational importance. Human resource management recognizes that today's generation of employees exhibits fundamentally different values and attitudes to those of predecessor generations, and that they bring with them clear and un-

31 N. Ryder, "Notes on the Concept of a Population," American Journal of Sociology, 69 (1964): 459. 
ambiguous intentions for their future. If the IDF has an advantage over corporate career alternatives, it resides in the fact that today's cadet/employee chooses to serve their country in a career that promises and advocates continual challenge. It becomes evident from my research that this challenge is met during cadet training, as exhibited by the assured confidence of cadet participant responses. Developments demonstrated within the cadet training environment and within the socialization methods employed by the Human Resources Section of the Defense Forces, whether intentional or not, have served to meet the needs of Generation Y. The expectation of continued challenge by new cadets is also evident, and it is quietly assumed that the IDF will continuously provide meaning and direction in the form of active and considered socialization processes that will define, support, and nurture these expectations. The Irish military, much like its corporate peers, exists in an environment of changing visions, policies, and objectives. This is particularly true not just in the aims of the organization, but also in the conditions under which it employs and maintains its employees.

The effective propagation of the policies and purposes of the Irish Defense Forces relies on the continued effectiveness of its employees. An enlightened productivity may be achieved if employee potential is considerately nurtured right from the beginning: "The more effective and efficient the socialization, the sooner a newcomer can be productive for the organization." 32 The individualized socialization method currently adopted by the IDF post-commissioning does not effectively embrace the dynamism of Generation $\mathrm{Y}$ in a way that inculcates and encourages the possibilities that this generation brings to bear. Members of Generation Y require qualified direction that enables the expectations of the organization to be set unambiguously. Once the expectations are set, the organizational goal is clarified, and the ability to measure performance is heightened. If the expectations of the new employee are not frequently clarified and qualified, the resultant ambiguity will disappoint and disillusion the cohort. Members of Generation Y embrace the prospect of challenge in a way that distinguishes them from previous generations, and underpins their choice of career path. According to Grainne Cullen, the attraction towards personal challenge appears more prevalent through interviews among those members of Generation $\mathrm{Y}$ who aspire to a career in the military as opposed to a career outside the military. ${ }^{33}$ Cullen highlights a surprising statistic from her research, in which she asked sixty cadet applicants what other career path they would pursue if they failed to achieve a cadetship. Almost fifty percent responded that they would pursue an entrepreneurial career path over the more stable and possibly expected civil, security, or banking environments. ${ }^{34}$

32 Ardts, et al., "The Breaking in of New Employees.”

33 Grainne Cullen, a psychologist working with the Irish Defense Forces, was interviewed by the author. All quotations here and below are taken from the author's records and notes from the interview.

34 Twenty-eight prospective Cadets chose an entrepreneurial career path as their preference should they be unsuccessful in their attempt to join the IDF. The choice of entrepreneur was not listed among the career alternative options, but rather was independently written in under the option "Other Careers.” 


\section{Why? The Benefits of Questioning}

Members of Generation Y will question everything. This is a natural progression from an upbringing that permits and encourages such inquisitiveness. It is a method through which clarity of purpose is identified and security of purpose is ensured. It is a quality, though, that in an organization such as the military may serve to undermine older views of obedience and respect for authority. However, it is a practice that for this generation assures continued and unabridged application to task. If the ability to openly question orders is removed, so too is the confidence and assuredness of the employee. Through questioning authority, the ability of the employee to confidently dispel ambiguity preserves the motivation to complete the task at hand and confidently justify the resultant product. This questioning trait is not something limited to Generation Y, but rather is a quality that has naturally evolved with society. Older generations may have been more capable of tempering the desire to question, based on the situation and on the audience. Hence, this questioning phenomenon is reasonably new to the military. To Generation $\mathrm{Y}$, however, questioning is a quality that is ingrained within the person, something that life has taught them should be practiced regardless of the weight or authority of the recipient. It is not done out of malice, but rather is well-intentioned and whole-heartedly justified in the eyes of the questioner.

The encouragement of questioning within the military can only serve to improve the transparency and legitimacy of what has traditionally been a hierarchical and bureaucratic structure. It cannot be ignored, though, that the latitude and flexibility that allow such a trait to openly express itself do not survive within the rigid chains of command that embody the military ethos. The military is possibly one of the last remaining organizational structures in which flexibility with regard to the questioning of authority cannot apply through all levels of the hierarchy. One aspect of a changing military, however, resides within the remit of operational planning processes for crisis management operations, in which the active encouragement of questioning ensures that all potential military responses are rigorously tested for every eventuality. The value of questioning in an open environment cannot be underestimated, and creating latitude for its productive employment within the confines of the employee's immediate environment should be embraced. Again, to cite Cullen, it is through questioning authority that one questions the organization, and it is only through questioning the organization that you enable organizational change. A future study based on this generation's progression might allow an evaluation of any correlation that might exist between rapid organizational change and the openness of that organization to employee inquisitiveness. Certainly, organizations today have achieved great success through open promotion of "flatter," less hierarchical management structures that actively encourage such a practice.

It follows that the questioning tendency inherent in Generation $\mathrm{Y}$ will be a byproduct of the new employee's attempts to proactively influence their own adjustment to their new work environment. Questioning is a method of self-socialization, which serves to elicit information about the new employee's environment. Studies show that "newcomers who frequently seek information and ask for feedback have more knowl- 
edge of the job and of the organization, and are more socially integrated."35 The employee's formative years within any organization are a hugely important period of adjustment, in which the initial promises of the career are either fulfilled or belied. In organizations that have adopted institutionalized methods of socialization, this is the period where mentoring or coaching is deployed and aimed at "the affirmation of the newcomer's own identity and quality."36 The indicated expectancy of some form of coaching on and after job commencement by the researched cadet group highlights a desire for methods of socialization that the IDF does not undertake as a formal practice. Coaching and/or mentoring is not a recognized pursuit within the Irish military, and when it is performed, while beneficial, it is entirely unregulated and informal. The annual performance appraisal system remains the sole mechanism whereby employees gain an insight into the level of their own performance against what is required or expected. Coaching and mentoring as a recognized organizational practice can serve to nurture this confident generation's aspirations, dispel ambiguities, and promote the levels of professionalism so strenuously demanded by today's changing military. The practice may serve to bridge the apparent disconnection between older military generations and the new cohort. It will serve to satisfy the insatiable questioning trait, and ultimately promote the career perseverance of members of Generation Y.

\section{Parallel Study Possibilities}

A factor that cannot be overlooked when debating the implications of generational change for organizations is whether or not work values remain constant throughout employment, or if in fact they change as employees mature into their chosen careers. Every employee will commence their career with pre-planned priorities and aspirations, but do these values change in consonance or dissonance with their employment? Are these values more influenced by generational experiences, or by age and maturation? Does the issue of work-life balance, so important to newer generations, imply that this factor alone will dictate employment values in future years? The issue of the achievement of a balanced lifestyle permeates Irish society today, and has become a necessary focus for the continued viability of commercial organizations. Given the nature and necessarily unique culture of the Irish Defense Forces, what adjustments (if any) can be made to accommodate the future requirements of the IDF's employees?

\section{Conclusion}

The Irish Defense Forces places great emphasis on the procedures and mechanisms employed in the recruitment and selection of prospective officers. The selection process is both rigorous and demanding, and is designed to identify those persons who possess the myriad qualities that define the ethos of military leadership and management. The process produces that small percentage of those persons who display the desired requirements, the "cream of the crop," as it were. The career motivations of today's

35 Ardts, et al., "The Breaking in of New Employees.”

36 Ibid. 
generation are generally more focused and calculated than those of previous generations. The successful lure resides within the career that offers diversity and consistency of challenge. The attraction is not the safe and secure, pensionable job that provides a reasonably comfortable refuge in less economically prosperous times. The problem now for the military consists in the maintenance of that challenge on and after commissioning. Career permanence is not as powerful a value as it once was. Thus, it is the retention of the engagement of the employee that now more than ever defines the challenge for the Irish Defense Forces.

It can be argued that youthful exuberance and motivation will always indicate a desire to change occupational course when occupational challenges fail to materialize. Certainly, as generations progress and mature, and their familial and financial responsibilities increase, their values may change, and occupational security can become paramount. Today's society, however, advocates occupational change as a natural matter of course. The robust state of the Irish economy has allowed the employee to become a valuable commodity, to be traded and upgraded across the spectrum of career opportunities that present themselves. Furthermore, previous studies have illustrated that "work values are more influenced by generational experiences than by age and maturation.",37

As one generation learns from its mistakes, these lessons are passed on to the next generation. The ideal for all generations, though, is to ultimately achieve the "life fully worth living." ${ }^{38}$ The members of Generation Y represent the workforce of the future. As modern progressive organizations embrace the use of psychological evaluation to assess and understand the motivations of their employees, and then seek to exceed them throughout their careers, so too should the military. In an age where the challenges facing the Irish Defense Forces are diversifying, the requirement to embrace employee values that in turn thrive on challenge is paramount to the successful achievement of organizational vision. Generation Y will meet and even exceed these challenges in an environment that recognizes, respects, and accedes to its needs.

${ }^{37}$ K.W. Smola and C.D. Sutton, "Generational Differences: Revisiting Generational Work Values for the New Millennium," Journal of Organizational Behavior 23 (2002): 379. 
THE QUARTERLY JOURNAL

\section{Bibliography}

Conger, Jay A.. "Winning 'Em Over: A New Model for Management in the Age of Persuasion." (2001).

Jorgensen, Bradley. "Baby Boomers, Generation X, and Generation Y: Policy Implications for Defence Forces in the Modern Era." Foresight 5, no. 4 (2003).

Kakabadse, A., J. Bank, and S. Vinnicombe. Working in Organisations, The Essential Guide for Managers in Today's Workplace. London: Penguin, 2005.

Loughlin, Catherine, and Julian Barling. "Young Workers' Work Values, Attitudes, and Behaviors." Journal of Occupational and Organizational Psychology 74, no. 4 (2001).

Ryder, N.. "Notes on the Concept of a Population." American Journal of Sociology (1964).

Sarkesian, S. C.. The Professional Army Officer in a Changing Society . Chicago: Nelson Hall Publishers, 1975.

Shepherd, H.A.. "On the Realization of Human Potential: A Path with a Heart." In The Organizational Behavior Reader. Englewood Cliffs, NJ: Prentice Hall, 2001.

Smola, K.W., and C.D. Sutton. "Generational Differences: Revisiting Generational Work Values for the New Millennium." Journal of Organizational Behavior 23 (2002).

Smola, K.W., and C.D. Sutton. "Generational Differences: Revisiting Generational Work Values for the New Millennium." Journal of Organizational Behavior 23 (2002).

Tulgan, Bruce, and Carolyn Martin. Managing Generation Y: Global Citizens Born in the Late Seventies and Early Eighties . Boston: HRD Press, 2001.

Zemke, R., C. Raines, and B. Filipczak. Generations at Work . New York: AMACOM, 2000 . 